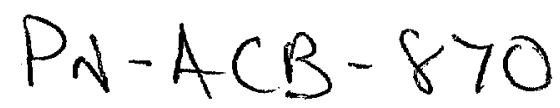

\title{
Properties of a thermal-processed beverage prepared from roasted partially defatted peanuts
}

\author{
Margaret J. Hinds's Larry R. Beuchat ${ }^{2 *}$ \& Manjeet S. Chinnan ${ }^{1}$ \\ 1 Centre for Food Safety and Quality Enhancement, Department of Food Science and Technology, University of \\ Georgia, USA \\ 2 Present address: Agricultural Research Program, 161 Carver Hall, North Carolina A\&T State University, Greensboro,
} USA

Summary The effects of two thermal processing methods on physical and sensory properties of a beverage prepared from finely ground, partially defatted roasted peanuts (Arachis hypogaea) were determined. Samples were either bottle-processed at $72{ }^{\circ} \mathrm{C}$ for $2 \mathrm{~min}$ or $111^{\circ} \mathrm{C}$ for $8 \mathrm{~min}$ after homogenizing at $72^{\circ} \mathrm{C}$, or kettle-pasteurized for $2 \mathrm{~min}$ at 72,77 or $82^{\circ} \mathrm{C}$ before homogenizing at 72,77 or $82^{\circ} \mathrm{C}$, respectively. Harsher thermal processing parameters increased the suspension stability and viscosity of bottle-processed beverage by 175 and $87 \%$, respectively, but had no influence on kettle-pasteurized beverage. Total solids (\%) and colour were not adversely affected by thermal processing. Beverage that was kettle-pasteurized and homogenized at $72{ }^{\circ} \mathrm{C}$ had low viscosity $(6.1-8.4 \mathrm{cps})$, typical roasted peanut flavour and little or no chalky mouthfeel, irrespective of whether carrageenan (stabilizer) or mono-diglyceride (emulsifier) were added to the formulation. Kettle-pasteurizing before homogenizing $\left(20.7 \times 10^{6} \mathrm{~Pa}\right)$ showed potential for producing beverages with physical and sensory attributes similar to commercial cow milk products.

Keywords Colour, sensory attributes, suspension stability, viscosity.

\section{Introduction}

Beverages developed from unroasted peanuts or soybeans are potential substitutes for cow's milk but they usually have undesirable characteristics such as beany or green off-flavours, suspension instability and chalky mouthfeel (Nelson et al., 1976; Beuchat \& Nail, 1978; Rubico et al., 1987; Chompreeda et al., 1989; Galvez et al., 1990; Lee \& Beuchat, 1992; Rustom et al., 1993). The need for improved sensory attributes (viz. flavour and mouthfeel) of oilseed beverages led us to formulate a beverage using finely ground, partially defatted roasted peanuts as the main ingredient

*Correspondent: Centre for Food Safety and Quality Enhancement, Department of Food Science and Technology, University of Georgia, Griffin, Georgia 30223-1797, USA. Fax: 770229 3216. e-mail:

lbeucha@cfsqe.griffin.peachnet.edu
(Hinds et al, 1997). This beverage, which contains no animal milk, has a pleasant roasted peanut flavour.

Heating alters the physical and chemical properties of homogenized liquids containing protein and fat (Van Boekel \& Walstra, 1989; Dalgleish, 1990; Sharma \& Dalgleish, 1993). Suspension stability of proteins in animal milks and oilseed beverages is a complex phenomenon influenced by many factors, including heating and cooling protocols (Catsimpoolas \& Meyer, 1970; Priepke et al., 1980; Schmidt et al., 1980; Gossett et al., 1984; Schmidt \& Morris, 1984; Sharma \& Dalgleish, 1993), protein and lipid concentration (Nelson et al., 1976; Sudo \& Ueda, 1990), type of stabilizer or emulsifier (Lo, 1971; Dziezak, 1988) and $\mathrm{pH}$, ionic strength and dielectric constant of the medium (Kumar et al., 1980; McWatters \& Cherry, 1982; Ihekoronye, 1990; Busk, 1984; Nsofor \& Anyanwu, 1992; Nsofor et al., 1993).

C 1997 Blackwell Science Ltd 
Sensory attributes of beverages prepared from unroasted oilseeds are influenced by heat processing and homogenizing protocols. For example, bottle-processed beverages have stronger cooked and raw flavours than kettle-pasteurized beverages (Rubico et al., 1988; Galvez et al., 1990), whereas homogenizing after kettle-pasteurizing facilitates production of beverages with smoother mouthfeel (Priepke et al., 1980).

Viscosities and suspension stabilities of soybean beverages (Priepke et al., 1980; Nsofor \& Anyanwu, 1992) and of cow's milk fortified with peanut flour (Schmidt et al., 1980) have been reported to increase when processing temperatures are elevated. Low viscosity and prolonged suspension stability are desirable physical properties of milk substitutes (Lo, 1971; Priepke et al., 1980; Galvez et al., 1990; Thekoronye, 1990; Sudo \& Ueda, 1990; Nsofor et al., 1993). Previous studies in which a beverage was prepared from roasted defatted peanuts indicated that the proteins may have been denatured during roasting (Hinds et al., 1997). Fat globule membranes may also have been altered during the defatting process. These changes could affect suspension stability, viscosity and colour of the beverage, which may in turn affect mouthfeel and appearance.

The objectives of this study were to evaluate the effects of two heat processing protocols on total solids, suspension stability, visual stability, viscosity and colour of a beverage prepared from partially defatted roasted peanuts. The beverage was homogenized, bottled and then heat processed (bottle-processed) or pasteurized in a kettle, homogenized and then bottled (kettle-pasteurized). The effects of thermal processing on selected sensory attributes of the beverage were also included.

\section{Materials and methods}

\section{Materials}

Roasted ( $163^{\circ} \mathrm{C}$ for $20 \mathrm{~min}$ ), dry-blanched and electronically sorted Florunner cultivar peanut (Arachis hypogaea) kernels (49\% fat, dry basis) were donated by Specialty Brands, Dromedary Plant, Woodbury, GA. Carrageenan (kappa:iota $[3: 1, w / w]$, Benlacta CM-61B ${ }^{\mathrm{TM}}$, Shemberg USA,
Searsport, ME) and hydrogenated monodiglyceride (Emuldan HV52K ${ }^{\mathrm{TM}}$, Grinsted Products, Inc., Industrial Airport, KS) were kindly provided. Granulated cane sugar, non-iodized table salt and commercial beverages [Kroger ${ }^{\mathrm{TM}}$ vitamin D (whole, $3.25 \%$ fat) milk, Kroger ${ }^{\mathrm{TM}}$ lowfat ( $2 \%$ fat) milk, Yoo-hoo ${ }^{\mathrm{TM}}$ chocolate flavoured drink and Kroger ${ }^{\mathrm{TM}}$ chocolate low-fat milk] were purchased from a local supermarket. Polyester screens (mesh nos. 143, 208, 275 and 380) (McMaster Company, Atlanta, GA) with mesh openings of 104, 74, 53 and $34 \mu \mathrm{m}$, respectively, were used to fabricate filters for the beverages.

\section{Beverage preparation}

Roasted peanuts were defatted, finely ground and wet blended (Fig. 1) according to procedures described by Hinds et al. (1997). Peanut slurry was filtered through a series of polyester screens with decreasing mesh openings (104-34 $\mu \mathrm{m})$. A commercial stabilizer $(0.02 \%$ Benlacta CM- $61 \mathrm{~B}$ or emulsifier $(0.20 \%$ Emuldan HV52K), was added

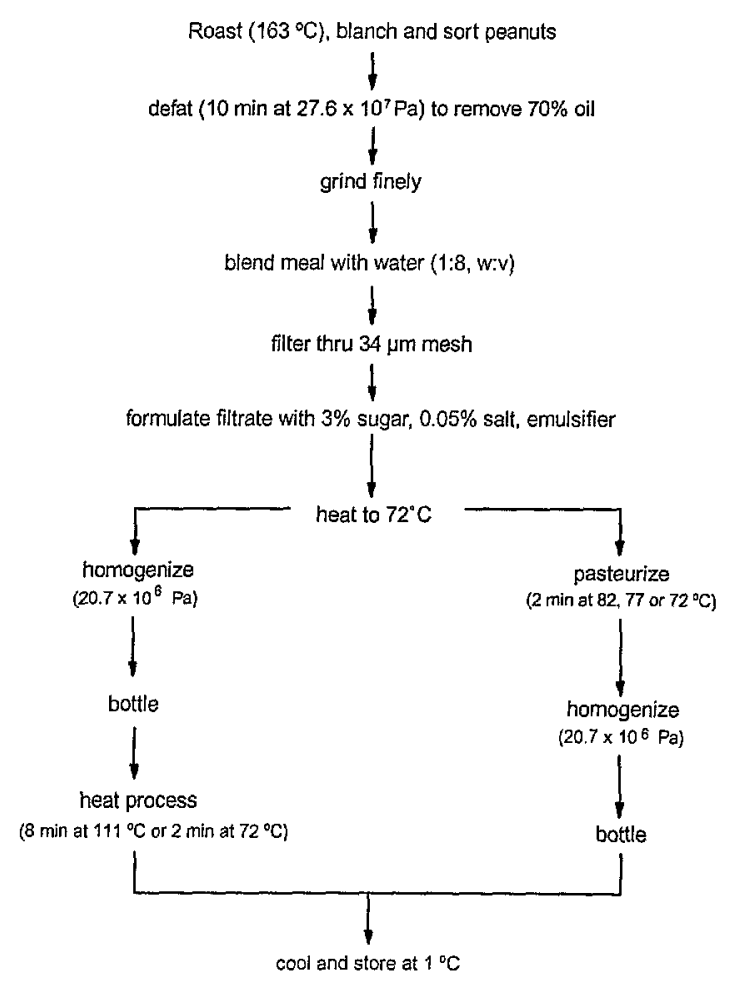

Figure 1 Flow diagram for preparation of peanut beverage. 
to the mixture. Selection of the levels of these additives was based on results of previous studies (Hinds et al., 1997).

The effects of five thermal processing protocols (two bottle-processed and three kettle-pasteurized) and two additives on viscosity, suspension stability, visual stability and colour of the beverage were evaluated in duplicate trials. Beverage containing either stabilizer or emulsifier and heated to $72{ }^{\circ} \mathrm{C}$ before being homogenized but not subjected to additional heat treatment served as a control. For each trial, twelve $200-\mathrm{mL}$ bottles of beverage were prepared for each of the ten treatments (five thermal processes $\times$ two stabilizing additives) and for each of the two controls.

\section{Heat-processing in bottles after homogenizing (bottle-processing)}

Each batch of beverage was homogenized twice at $72^{\circ} \mathrm{C}$ in a two-stage laboratory homogenizer (Model 15MR-8TBA, APV Gaulin, Inc., Everett, MA) with $20.7 \times 10^{6} \mathrm{~Pa}$ applied at both stages. Thermocouples were attached to the inlet, outlet and cylinder head of the homogenizer. To achieve and maintain a temperature of $72{ }^{\circ} \mathrm{C}$ at the cylinder head, $1 \mathrm{~L}$ of water $\left(95^{\circ} \mathrm{C}\right)$ was recycled for 2 min through the homogenizer before each batch of beverage was homogenized. Beverage temperatures at inlet and outlet ports of the homogenizer were $71-72{ }^{\circ} \mathrm{C}$. Peanut beverages were filled into sterile $200-\mathrm{mL}$ glass jars; mild heat $\left(72^{\circ} \mathrm{C}, 2 \mathrm{~min}\right)$ or a more severe $\left(111^{\circ} \mathrm{C}, 8 \mathrm{~min}\right)$ treatment was then applied. A laboratory pressure cooker or a controlled-temperature water bath was used to process bottled beverages at $111^{\circ} \mathrm{C}$ or $72{ }^{\circ} \mathrm{C}$, respectively. For beverages processed at $72^{\circ} \mathrm{C}$, initial heating time commenced when the internal temperature reached $72{ }^{\circ} \mathrm{C}$.

\section{Pasteurizing in kettles before homogenizing and bottling (kettle-pasteurizing)}

Three pasteurizing temperatures $(72,77$ and $82^{\circ} \mathrm{C}$ ) were used. Each batch of beverage was pasteurized in a steam-jacketed kettle for $2 \mathrm{~min}$ then homogenized at the same temperature. Homogenizing and filling operations were similar to those used for bottle-processed samples. To achieve temperatures of 77 or $82^{\circ} \mathrm{C}$ at the cylin- der head, $1 \mathrm{~L}$ of hot $\left(95^{\circ} \mathrm{C}\right)$ water was recycled through the homogenizer for 4 or $10 \mathrm{~min}$, respectively, before the beverage was homogenized. Beverage temperatures at inlet and outlet ports were $76-77$ and $81^{\circ} \mathrm{C}$, respectively, for beverages homogenized at 77 or $82^{\circ} \mathrm{C}$.

All bottled beverages were cooled in tap water $\left(25^{\circ} \mathrm{C}\right)$ for $30 \mathrm{~min}$, then in an ice-slurry bath $\left(10^{\circ} \mathrm{C}\right.$ ) for $1 \mathrm{~h}$, and stored at $1^{\circ} \mathrm{C}$ for 7 days before being analysed.

\section{Physical and chemical analyses}

Triplicate bottles per treatment were analysed for each test. Total solids, viscosity, suspension stability, and colour of the peanut beverages and commercial milk products were determined according to procedures described by Hinds et al. (1997). The objective measurement of suspension stability was indicated by the ratio of solids in the upper and lower thirds of the bottled samples. Visual stability, i.e. visible settling of solids in the beverage, was determined from the appearance of the bottled product to a potential consumer. Beverage samples were observed for separation into two layers. When a line of demarcation was detected, the ratio of height of solid particulates to total height of beverage was calculated and defined as the visual index. If no separation was observed, the visual index was 1.00 (Priepke et al., 1980). The lipid content in defatted peanut kernels was determined by method 27.006(b) of AOAC (1984) using a Goldfisch fat extractor (Labconco Corp., Kansas, MO). Protein content and nitrogen solubility index of the defatted meal were determined by methods $46-11$ and $46-23$, respectively, of AACC (1976).

\section{Sensory screening}

Eight panellists, trained in descriptive analysis to evaluate sensory attributes of peanuts, peanut products and beverages, participated in this exercise. A total of six samples (formulations bottleprocessed at $111^{\circ} \mathrm{C}$ or kettle-pasteurized at $72^{\circ} \mathrm{C}$ or $82^{\circ} \mathrm{C}$ ) were randomly presented to each panellist in one session. Samples were served at $15^{\circ} \mathrm{C}$ in $60-\mathrm{mL}$ plastic cups identified by random threedigit codes. Panellists were required to stir each sample with a clean stirrer for $30 \mathrm{~s}$ before evalu- 
ating it. Water and water crackers were provided for clearing palates between samples. Overall appearance, colour, flavour (viz. roasted peanut, beany, cooked, sulphur, woody, musty, rancid, oily, sweet, bitter), viscosity and mouthfeel of experimental peanut beverages were analysed using word category scales. The scales for flavour components and chalky mouthfeel were: none, very mild, mild/slight, moderate, strong and very strong. Viscosity of the experimental beverage was compared with commercial whole and lowfat cow's milks using the following scale: lower than low-fat milk, similar to low-fat milk, higher than low-fat but lower than whole milk, similar to whole milk, higher than whole milk and very much higher than whole milk. Numerical values of zero (none/lower than low-fat milk) to five (very strong/very much higher than whole milk) were subsequently assigned to responses to facilitate statistical analyses. Because this was a screening exercise, panellists were seated in the same room to facilitate post-evaluation round-table discussion on the attributes of the experimental beverages.

\section{Statistical analysis}

ANOVA (General Linear Models procedure), significant differences between means $(\alpha=0.05$, Duncan's Multiple Range test) and correlation coefficients (Pearson product-moment correlation) were determined using the SAS (1985) computer package.

\section{Results and discussion}

\section{Chemical composition}

The defatted peanut meal from which the beverage was prepared contained $14.7 \%$ fat and $52.1 \%$ protein (dry basis), and had a nitrogen solubility index of 25.2 .

\section{Total solids}

Solids (\%) content in the peanut beverage (12.6-13.9\%) (Table 1) compared favourably with that in commercial full-fat cow's milk (11.7\%), chocolate flavoured drink (14.2\%) and chocolate low-fat milk (15.2\%), and also with U.S. Food

Table 1 Mean physical properties* ( \pm s.d., $n=3$ ) of defatted, homogenized peanut beverages containing carrageenan stabilizer (CM) or hydrogenated mono-diglyceride emulsifier (HV) and either bottle or kettle processed. Beverages were stored at $1^{\circ} \mathrm{C}$ for 7 days before being analysed

\begin{tabular}{|c|c|c|c|c|c|c|c|}
\hline \multirow[t]{2}{*}{ Property } & \multirow[t]{2}{*}{ Additive } & \multirow[t]{2}{*}{ Control } & \multicolumn{2}{|l|}{ Bottle-processed } & \multicolumn{3}{|c|}{ Kettle-pasteurized } \\
\hline & & & $72{ }^{\circ} \mathrm{C}$ & $111^{\circ} \mathrm{C} \neq$ & $72^{\circ} \mathrm{C}$ & $77^{\circ} \mathrm{C}$ & $82^{\circ} \mathrm{C}$ \\
\hline \multirow{2}{*}{$\begin{array}{l}\text { Total Solids } \\
\text { (\%) }\end{array}$} & $\mathrm{CM}$ & $12.6 \pm 0.02 d$ & $12.6 \pm 0.07 d$ & $12.6 \pm 0.01 d$ & $12.8 \pm 0.49 \mathrm{~cd}$ & $13.4 \pm 0.17 b$ & $13.3 \pm 0.41 b$ \\
\hline & HV & $13.0 \pm 0.03 c$ & $13.0 \pm 0.03 c$ & $13.0 \pm 0.02 c$ & $13.9 \pm 0.27 a$ & $13.8 \pm 0.03 a$ & $13.8 \pm 0.28 a$ \\
\hline \multicolumn{8}{|c|}{ Suspension } \\
\hline stability & $\mathrm{CM}$ & $0.37 \pm 0.030 \mathrm{c}$ & $0.38 \pm 0.040 \mathrm{c}$ & $0.72 \pm 0.015 a$ & $0.40 \pm 0.037 \mathrm{bc}$ & $0.48 \pm 0.069 b$ & $0.44 \pm 0.062 b c$ \\
\hline index & HV & $0.40 \pm 0.025 b c$ & $0.40 \pm 0.040 \mathrm{bc}$ & $0.70 \pm 0.055 a$ & $0.47 \pm 0.038 b$ & $0.46 \pm 0.053 b$ & $0.45 \pm 0.050 b c$ \\
\hline \multicolumn{8}{|l|}{ Visual } \\
\hline stability & CM & $0.57 \pm 0.006 f$ & $0.58 \pm 0.010 \mathrm{ef}$ & $0.92 \pm 0.010 \mathrm{a}$ & $0.62 \pm 0.025 \mathrm{~cd}$ & $0.60 \pm 0.019 \mathrm{def}$ & $0.62 \pm 0.019 \mathrm{~cd}$ \\
\hline index & HV & $0.48 \pm 0.000 \mathrm{~h}$ & $0.51 \pm 0.006 \mathrm{~g}$ & $0.85[ \pm 0.010 \mathrm{~b}$ & $0.63 \pm 0.016 \mathrm{c}$ & $0.61 \pm 0.016 \mathrm{cde}$ & $0.62 \pm 0.031 \mathrm{~cd}$ \\
\hline \multirow{2}{*}{$\begin{array}{l}\text { Viscosity } \\
\text { (cps) }\end{array}$} & $\mathrm{CM}$ & $2.4 \pm 0.06 f$ & $4.3 \pm 0.0 \mathrm{e}$ & $17.4 \pm 0.0 \mathrm{a}$ & $6.1 \pm 0.31 d$ & $6.4 \pm 0.91 d$ & $6.5 \pm 0.54 d$ \\
\hline & HV & $2.0 \pm 0.06 \mathrm{~g}$ & $2.1 \pm 0.0 \mathrm{~g}$ & $17.4 \pm 0.0 \mathrm{a}$ & $8.4 \pm 0.44 b$ & $7.4 \pm 0.35 c$ & $6.7 \pm 0.06 \mathrm{~d}$ \\
\hline \multirow[t]{2}{*}{ Hue angle ${ }^{\beta}$} & $\mathrm{CM}$ & $68.9 \pm 0.05 \mathrm{~cd}$ & $66.5 \pm 0.02 \mathrm{fg}$ & $68.0 \pm 0.08 \mathrm{de}$ & $70.8 \pm 0.00 \mathrm{ab}$ & $69.9 \pm 0.09 b c$ & $69.4 \pm 0.02 c$ \\
\hline & HV & $67.2 \pm 0.03 e f$ & $59.6 \pm 0.02 i$ & $64.7 \pm 0.08 \mathrm{~h}$ & $71.8 \pm 0.05 a$ & $71.2 \pm 0.03 a$ & $69.8 \pm 0.07 \mathrm{bc}$ \\
\hline \multirow[t]{2}{*}{ L value ${ }^{8}$} & $\mathrm{CM}$ & $71.5 \pm 0.09 a$ & $65.2 \pm 1.37 \mathrm{cde}$ & $72.2 \pm 0.15 a$ & $65.5 \pm 1.14 \mathrm{cde}$ & $64.2 \pm 2.15 \mathrm{def}$ & $63.9 \pm 1.04 \mathrm{ef}$ \\
\hline & HV & $69.1 \pm 0.09 b$ & $53.3 \pm 0.28 \mathrm{~g}$ & $65.4 \pm 0.48 \mathrm{cde}$ & $65.4 \pm 1.63 \mathrm{cde}$ & $66.3 \pm 1.91 \mathrm{c}$ & $65.5 \pm 0.42 \mathrm{cde}$ \\
\hline \multirow[t]{2}{*}{ Chroma } & $\mathrm{CM}$ & $7.5 \pm 0.05 \mathrm{de}$ & $7.2 \pm 0.03 \mathrm{e}$ & $8.8 \pm 0.08 a b$ & $8.8 \pm 0.09 a b$ & $8.3 \pm 0.02 a b c$ & $8.2 \pm 0.08 \mathrm{bc}$ \\
\hline & HV & $7.0 \pm 0.02 \mathrm{e}$ & $4.7 \pm 0.01 f$ & $7.0 \pm 0.07 \mathrm{e}$ & $9.0 \pm 0.06 a$ & $8.8 \pm 0.0 a b$ & $8.3 \pm 0.01 a b c$ \\
\hline
\end{tabular}

* Means within each physical property that are followed by the same letter are not significantly different at $(\alpha=0.05)$.

$\ddagger$ Processing time at $111^{\circ} \mathrm{C}$ was $8 \mathrm{~min}$. All other samples were procesed for $2 \mathrm{~min}$.

${ }^{\beta}$ Hue angle $\mathrm{h}^{\circ}: 0^{\circ}=$ red, $90^{\circ}=$ yellow.

${ }^{\circ} \mathrm{L}$ value: $0=$ black, $100=$ white. 
and Drug Administration specifications of $\geq 11.5 \%$ total solids in milk substitutes. The solids content in bottle-processed beverages (12.6$13.0 \%$ ) was not affected by heat treatment. Beverages containing emulsifier had more solids $(13.0 \%)$ than those containing stabilizer $(12.6 \%)$. Generally, the kettle-pasteurized beverages contained more solids $(12.8-13.9 \%)$ than those that were bottle-processed. This was expected because of possible water evaporation during kettle-pasteurizing. Solids content was influenced mainly by stabilizer and emulsifier. The consistently lower levels of solids in beverages containing stabilizer compared with those containing emulsifier were probably because it was added at a concentration ten times greater than that of stabilizer.

\section{Suspension and visual stability}

Suspension stability indices of the heat-processed peanut beverage ranged from $0.37-0.72$ (Table 1). Suspension stability indices of commercial whole (full-fat) milk, chocolate low-fat milk and chocolate drink were $1.0,1.0$ and 0.96 , respectively. Visual stability in the chocolate drink $(0.11)$ was lowest when compared with other commercial milks (1.0) and peanut beverages $(0.48-0.92)$.

Harsher processing conditions $(8 \mathrm{~min}$ at $111^{\circ} \mathrm{C}$ ) improved the stability of the bottleprocessed samples. Schmidt et al. (1980) also observed an increase in suspension stability when peanut-fortified milks were heated at $\geq 85^{\circ} \mathrm{C}$. Denaturation and aggregation of protein molecules are heat dependent processes. The kinetics of denaturation relative to aggregation may determine the structure and stability of the aggregated protein (Gossett et al., 1984). The process of aggregation between oilseed proteins and the properties of their aggregates differs from those of other common proteins, for example, milk (Schmidt \& Morris, 1984). When liquids containing soy protein are heated at $\geq 100^{\circ} \mathrm{C}$, gel type aggregates involving covalent disulphide bonds are formed. These aggregates have considerably high water-holding capacity and exhibit low syneresis (Catsimpoolas \& Meyer, 1970; Schmidt \& Morris, 1984). A comparison of suspension stability indices between bottle-processed beverages and other beverages suggests that processing at $111^{\circ} \mathrm{C}$ may have facilitated formation of gel type protein aggregates with high water-holding capacity.

Suspension stabilities of kettle-processed beverage were neither increased at higher pasteurization temperatures nor markedly different from those of unprocessed controls, suggesting that protein complexes formed during heating at $\leq 82{ }^{\circ} \mathrm{C}$ were broken down during subsequent homogenizing operations. Therefore, temperatures $>82{ }^{\circ} \mathrm{C}$ or a longer heating time may be required to form protein gels and hydrophilic protein-lipid complexes in peanut beverage, whereas dissociation of protein complexes formed during pasteurization may be prevented by homogenizing at $72-77^{\circ} \mathrm{C}$.

The effects of homogenizing temperature and pressure on suspension stability of peanut beverages observed here are somewhat different from those of beverages prepared from unroasted peanuts and soybeans by other researchers. Soybean beverages heated to $82{ }^{\circ} \mathrm{C}$, then homogenized twice at $24.1 \times 10^{6} \mathrm{~Pa}$ had suspension and visual stability indices of 0.9 and 1.0 , respectively, after a 7-day quiescent storage time at $1.1{ }^{\circ} \mathrm{C}$ (Nelson et al., 1976; Priepke et al., 1980). Rubico et al. (1987) prepared beverages from nondefatted and partially defatted ( $40 \%$ oil removed) unroasted peanuts. Beverages which were heated to $71^{\circ} \mathrm{C}$, homogenized twice at $13.8 \times 10^{6}$ or $20.7 \times$ $10^{6} \mathrm{~Pa}$ then heated at 110 or $121^{\circ} \mathrm{C}$ for $3 \mathrm{~s}$ had a suspension stability index of 1.0 after a 10 -day quiescent storage at $1{ }^{\circ} \mathrm{C}$. Soluble protein $(\%)$ and gelation properties of meals prepared from unheated peanut kernels and kernels dry roasted at $160^{\circ} \mathrm{C}$ for $20 \mathrm{~min}$ were reported by Patil et al. (1993) to be 15.8 and $22.1 \%$, and 16 and $14 \mathrm{~g} 100$ $\mathrm{mL}^{-1}$, respectively. The nitrogen solubility index of the meal used to prepare our beverage was $25.2 \%$. Considering these observations, the roasting treatments used in our study probably did not adversely affect gelation properties of the proteins. The relatively high suspension stability exhibited by bottle-processed beverages supports this hypothesis. Removal of $70 \%$ of the oil from peanuts may have resulted in a limited quantity of fat globules to form lipid-protein complexes. Although homogenizing parameters may have been adequate to produce small fat globules, there was insufficient total surface area available on the fat globules for binding with protein. 
Proteins unable to gel due to relatively low pasteurizing temperatures or to bind with fat globules, formed precipitates. During preparation of a beverage from peanuts, Rubico et al. (1987) filtered slurries through a muslin cloth, whereas we filtered slurries through a $34-\mu \mathrm{m}$ screen to impart a smoother mouthfeel. The relatively smaller particles in the filtrate resulting from our procedure may have required higher activation energy than that provided by pasteurization for subsequent gelation in the beverage. Because of the lower fat content and smaller particles in our beverage, a different combination of pasteurizing and homogenizing parameters may be necessary to improve suspension stability.

There were no significant differences in suspension stability of peanut beverages caused by stabilizer or emulsifier (Table 1). However, control beverages and bottle-processed beverages containing stabilizer exhibited less visual separation compared to samples containing emulsifier. The stabilizer, Benlacta CM-61B, contains kappa-carrageenan, a sulphated linear polysaccharide which stabilizes by forming threadlike networks and protein-polysaccharide complexes (Shand et al., 1994), whereas mono- and diglycerides in the emulsifier (Emuldan HV52K) would emulsify by reducing surface tension at the interface between oil and water in the beverage. The presence of 3,6-anhydride groups on $\kappa$ - and ı-carrageenan molecules favours formation of intermolecular helical conformations in aqueous systems above $50{ }^{\circ} \mathrm{C}$ (Pomeranz, 1991; Samant et al., 1993). Thus, in the controls and bottle-processed beverages containing stabilizer, water and solids may have been bound to or suspended in the carrageenan network and therefore imparted a higher visual stability. Homogenizing operations used to prepare kettle-pasteurized beverages probably disrupted the carrageenan network, thereby causing no differences in visual stability between samples containing stabilizer or emulsifier.

\section{Viscosity}

Beverages bottle-processed at $111^{\circ} \mathrm{C}$ for $8 \mathrm{~min}$ were the most viscous (17.4 cps, Table 1$)$. Differences in viscosity among the bottleprocessed beverages are attributed to increased unfolding and aggregation of protein molecules and formation of hydrophilic protein-lipid complexes as severity of thermal treatment was increased. Rubico et al. (1988) also observed increases in viscosity when increased heat treatments were applied to beverages prepared from unroasted peanuts. Commercial whole milk, lowfat milk, chocolate low-fat milk and chocolate drink had viscosities of $2.0 \pm 0.00,2.0 \pm 0.00$, $12.7 \pm 0.26$ and $4.9 \pm 0.06 \mathrm{cps}$, respectively. Bottle-processing peanut beverage at $111^{\circ} \mathrm{C}$ for $8 \mathrm{~min}$ after homogenizing would therefore be inappropriate for obtaining products with viscosity similar to commercial milks.

Heat processing was not the main factor influencing viscosity of the kettle-pasteurized samples. Decreases in viscosity of beverage containing emulsifier as pasteurization temperature was increased suggest that bonds formed between protein molecules during pasteurization were more easily broken at higher homogenization temperatures. Beverages that were kettle-pasteurized at $72^{\circ} \mathrm{C}$ for $2 \mathrm{~min}$ were more viscous than those bottle-processed using similar parameters. This difference may have arisen from greater interaction among protein molecules and between protein molecules and fat globules during stirring of the formulations in the kettle.

Strong positive correlations between viscosity and suspension stability $(0.965, \alpha=0.0001)$ and between viscosity and visual stability $(0.987, \alpha=$ 0.0001 ) were observed for the bottle-processed beverages. Respective correlation coefficients for kettle-pasteurized beverages were $(0.284, \alpha=$ $0.0928)$ and $(0.352, \alpha=0.0352)$. This suggests that beverages with relatively high suspension stability and low viscosity might be more easily obtained if beverages are kettle-pasteurized then homogenized.

\section{Colour}

Peanut beverages had orange-yellow hues (Table 1). However, bottle-processed beverages were more orange $\left(\mathrm{h}^{0}=59.6-68.0\right)$, whereas kettlepasteurized beverages were more yellow $\left(h^{0}=\right.$ 69.8-71.8) than the controls $\left(h^{0}=67.2-68.9\right)$. Harsher bottle-processing parameters produced lighter coloured beverages but no significant $(\alpha=$ 0.05 ) differences in lightness arose from higher 
kettle-pasteurizing temperatures. Values observed for chroma were within a narrow range. Homogenizing and pasteurizing parameters appeared to have no effect on chroma of kettlepasteurized beverages. However, brightness of bottle-processed beverages increased as severity of processing conditions was increased, and beverages containing stabilizer were brighter than those with emulsifier. Generally, heat processing produced beverages that were slightly darker, less bright and more orange than beverages heated to $71^{\circ} \mathrm{C}$ only and then homogenized, bottled and cooled (Hinds et al., 1997).

\section{Sensory attributes}

Preliminary sensory evaluation of the peanut beverages indicated that beverages bottle-processed at $111^{\circ} \mathrm{C}$ for $8 \mathrm{~min}$ were the most viscous, very chalky and imparted slightly bitter and beany aftertastes, whereas kettle-pasteurized beverages had stronger roasted peanut flavour and smoother mouthfeel (Table 2). Samples containing emulsifier and kettle-pasteurized at $72{ }^{\circ} \mathrm{C}$ for $2 \mathrm{~min}$ had the strongest roasted peanut flavour, smooth mouthfeel and viscosity similar to cow's milk. It appears that protein complexes which stabilized the bottle-processed $\left(111^{\circ} \mathrm{C}\right)$ beverage also contributed to its chalky mouthfeel. Galvez et al. (1990) observed an increase in bitter and sulphur aromatic flavours when beverages prepared from unroasted peanuts were processed at temperatures $>100^{\circ} \mathrm{C}$.

\section{Conclusions}

Although our bottle-processed $\left(111^{\circ} \mathrm{C}\right)$ beverages were more stable than those that were kettle-pasteurized, observations on physical and sensory properties indicate that the peanut beverage should be kettle-pasteurized at $<100{ }^{\circ} \mathrm{C}$, then homogenized. Optimization experiments to develop a process to yield a beverage from roasted partially defatted peanuts with acceptable sensory attributes and high suspension stability need to be performed. If these products are not physically stable, directions to 'shake before consumption', similar to those for commercial chocolate drinks, could be provided on the labels.

\section{Acknowledgements}

This research was supported in part by the Peanut Collaborative Research Support Program of US Agency for International Development, USAID grant No. DAN-4048-G-0041-00.

Table 2 Mean sensory attributes* ( \pm s.d., $n=8$ ) of defatted homogenized peanut beverage containing carrageenan stabilizer (CM) or hydrogenated mono-diglyceride emulsifier (HV) and either bottle or kettle processed. Beverages were stored at $1^{\circ} \mathrm{C}$ for 7 days before being analysed

\begin{tabular}{|c|c|c|c|c|}
\hline \multirow[b]{2}{*}{ Property } & \multirow[b]{2}{*}{ Additive } & \multirow{2}{*}{$\frac{\text { Bottle-processed }(8 \mathrm{~min})}{111^{\circ} \mathrm{C}}$} & \multicolumn{2}{|c|}{ Kettle-pasteurized (2 $\mathrm{min}$ ) } \\
\hline & & & $72{ }^{\circ} \mathrm{C}$ & $82^{\circ} \mathrm{C}$ \\
\hline \multicolumn{5}{|l|}{ Flavour $^{\beta}$} \\
\hline \multirow[t]{2}{*}{ Roasted peanut } & $\mathrm{CM}$ & $0.5 \pm 0.93 d$ & $1.1 \pm 0.64 \mathrm{~cd}$ & $2.9 \pm 0.35 b$ \\
\hline & HV & $1.8 \pm 0.71 \mathrm{c}$ & $3.8 \pm 0.71 a$ & $2.5 \pm 0.53 b$ \\
\hline \multirow[t]{2}{*}{ Beany } & $\mathrm{CM}$ & $2.3 \pm 1.39 a$ & $1.1 \pm 0.99 b$ & $0.4 \pm 0.52 b$ \\
\hline & HV & $0.8 \pm 1.04 b$ & $0.4 \pm 0.52 b$ & $1.3 \pm 0.89 b$ \\
\hline \multirow[t]{2}{*}{ Cooked } & $\mathrm{CM}$ & $1.1 \pm 1.55 \mathrm{a}$ & $0.8 \pm 1.16 a b$ & $0.4 \pm 0.52 a b$ \\
\hline & HV & $0.5 \pm 0.93 a b$ & $0.5 \pm 0.53 b$ & $0.0 \pm 0.00 \mathrm{~b}$ \\
\hline \multirow{2}{*}{ Bitter } & $\mathrm{CM}$ & $0.4 \pm 1.06 a b$ & $0.3 \pm 0.71 b$ & $0.8 \pm 1.04 a b$ \\
\hline & HV & $1.1 \pm 0.99 a$ & $0.0 \pm 0.00 \mathrm{~b}$ & $0.0 \pm 0.00 \mathrm{~b}$ \\
\hline \multirow[t]{2}{*}{ Chalky Mouthfeel ${ }^{\mathrm{B}}$} & $\mathrm{CM}$ & $2.9 \pm 1.46 \mathrm{ab}$ & $1.6 \pm 0.92 b c$ & $2.6 \pm 0.92 a b c$ \\
\hline & HV & $3.4 \pm 1.60 \mathrm{a}$ & $1.4 \pm 1.19 c$ & $1.5 \pm 0.93 c$ \\
\hline \multirow[t]{2}{*}{$V_{i s c o s i t y}{ }^{8}$} & $\mathrm{CM}$ & $4.9 \pm 0.35 a$ & $2.4 \pm 0.74 \mathrm{c}$ & $2.8 \pm 0.89 \mathrm{c}$ \\
\hline & HV & $3.6 \pm 0.74 b$ & $2.0 \pm 1.20 \mathrm{c}$ & $2.1 \pm 0.99 c$ \\
\hline
\end{tabular}

*Means within each sensory attribute that are followed by the same letter are not significantly different at $(\alpha=0.05)$.

${ }^{\beta}$ Category scale: $0=$ none, $1=$ very mild, $2=$ slight $/ \mathrm{mild}, 3=$ moderate, $4=$ strong, $5=$ very strong.

${ }^{8}$ Category scale: $0=$ lower than low-fat milk, $1=$ similar to low-fat milk, $2=$ higher than low-fat but lower than whole milk, $3=$ similar to whole milk, $4=$ higher than whole milk, $5=$ very much higher than whole milk. 


\section{References}

AACC (1976). Approved methods of the AACC. St. Paul, MN: American Association of Cereal Chemists.

AOAC (1984). Official Methods of Analysis, 14th edn. P. 501. Washington, DC: Association of Official Analytical Chemists.

Beuchat, L.R. \& Nail, B.J. (1978). Fermentation of peanut milk with Lactobacillus bulgaricus and $L$. acidophilus. Journal of Food Science, 43, 1109-1112.

Busk, G.C., Jr (1984). Polymer-water interactions in gelation. Food Technology, 38(5), 59-64.

Catsimpoolas, N. \& Meyer, E.W. (1970). Gelation phenomena of soybean globulins. I. Protein-protein interactions. Cereal Chemistry, 47, 559-570.

Chompreeda, P., Haruthaithanasan, V., Oupadissakoon, C. \& Suknak, K. (1989). Development of a chocolate flavored peanut beverage. Journal of Food Science, 54, $1359-1360$.

Dalgeish, D.G. (1990). Denaturation and aggregation of serum proteins and casein in heated milk. Journal of Agricultural and Food Chemistry, 38, 1995-1999.

Dziezak, J.D. (1988). Emulsifiers: the interfacial key to emulsion stability. Food Technology, 42(10), 172-186.

Galvez, F.C.F., Resurreccion, A.V.A. \& Koehler, P.E. (1990). Optimization of processing of peanut beverage Journal of Sensory Studies, 5, 1-17.

Gossett, P.W., Rizvi, S.S.H. \& Baker, R.C. (1984). Quantitative analysis of gelation in egg protein systems. Food Technology, 38(5), 67-74, 96.

Hinds, M.J., Beuchat, L.R. \& Chinnan, M.S. (1996). Effects of homogenization pressure and stabilisers on some physical characteristics of a beverage prepared partially defatted, from roasted peanuts. Plant Foods for Human Nutrition (in press).

Ihekoronye, A.I. (1990). Non-soy vegetable proteins for food formulations - The author's experience. In: Proceedings of Nigerian Institute of Food Science and Technology (Eastern Chapter) Symposium on Bany Foods (edited by J.C. Okaka). Pp. 55-59. Cited in International Joumal of Food Science and Technology (1993), 28, 499-504.

Kumar, K.D.N., Nandi, P.K. \& Rao, M.S.N. (1980). Reversible gelation of arachin. International Journal of Peptide Protein Research, 15, 67-72.

Lee, C. \& Beuchat, L.R. (1992). Chemical, physical and sensory characteristics of peanut milk as affected by processing conditions. Journal of Food Science, 57, $401-405$.

Lo, K.S. (1971). Process for preparing a soybean beverage. U.S. patent 3, 563, 762 .

McWatters, K.H. \& Cherry, J.P. (1982). Potential food uses of peanut seed proteins. In: Peanut Science and Technology (edited by H.E. Pattee \& C.T. Young). Pp. 689-736. Yoakum, TX: American Peanut Research and Education Society, Inc.

Nelson, A.I., Steinburg, M.P. \& Wei, L.S. (1976). Illinois process for preparation of soymilk. Journal of Food Science, 41, 57-61.
Nsofor, L.M. \& Anyanwu, K.B. (1992). Effect of heat processing on refrigerated shelf-life of concentrated soymilk beverage. Journal of Food Science and Technology, 29, 40-44.

Nsofor, L.M., Uzuegbu, D.N., Chukwuma, A.K. \& Udechukwu, A. (1993). Storage stability of concentrated soymilk: evaluation of cowmilk concentrate and salts' addition and soybean acidsteeping. International Journal of Food Science and Technology, 28, 499-504.

Patil, U.G., Chavan, J.K., Kadam, S.S. \& Salunkhe, D.K. (1993). Effects of dry heat treatments to peanut kernels on the functional properties of the defatted meal. Plant Foods for Human Nutrition, 43, 157-162.

Pomeranz, Y. (1991). Functional Properties of Food Components, 2nd edn. Pp. $79-115$ and 248-380. San Diego: Academic Press, Inc.

Priepke, P.E., Wei, L.S., Nelson, A.I. \& Steinberg, M.P. (1980). Suspension stability of Illinois soybean beverage. Journal of Food Science, 45, 242-245.

Rubico, S.M., Resurreccion, A.V.A., Frank, J.F. \& Beuchat, L.R. (1987). Suspension stability, texture, and colour of high temperature treated peanut beverage. Journal of Food Science, 52, 1676-1679.

Rubico, S.M., Resurreccion, A.V.A. \& Beuchat, L.R. (1988). Comparison of sensory properties and headspace volatiles of a peanut beverage processed at different temperature and time conditions. Journal of Food Science, 53, 176-180.

Rustom, I.Y.S., Lopez-Leiva, M.H. \& Nair, B.M. (1993). Extraction of peanut solids with water - effect of the process and enzymatic hydrolysis. LebensmittelWissenschaft u.-Technology, 26, 72-75.

Samant, S.K., Singhal, R.S., Kulkarni, P.R. \& Rege, D.V. (1993). Protein-polysaccharide interactions: a new approach in food formulations. International Journal of Food Science and Technology, 28, 547-562.

SAS Institute, Inc. (1985). SAS User's Guide: Statistics, 5th edn. Cary, NC: SAS Institute, Inc.

Schmidt, R.H. \& Morris, H.A. (1984). Gelation properties of milk proteins, soy proteins, and blended protein systems. Food Technology, 38(5), 85-94, 96.

Schmidt, R.H., Sistrunk, C.P., Richter, R.L. \& Cornell, J.A. (1980). Heat treatment and storage effects on texture characteristics of milk and yogurt systems fortified with oilseed proteins. Journal of Food Science, 45, 471-475.

Shand, P.J., Sofos, J.N. \& Schmidt, G.R. (1994). Kappacarrageenan, sodium chloride and temperature affect yield and texture of structured beef rolls. Journal of Food Science, 59, 282-287.

Sharma, S.K. \& Dalgeish, D.G. (1993). Interactions between milk serum proteins and synthetic fat globule membrane during heating of homogenized whole milk. Journal of Agricultural and Food Chemistry, 41, 1407-1412.

Sudo, R. \& Ueda, T. (1990). Process for preparing highfat soybean milk. U.S. patent $4,902,526$.

Van Boekel, M.A.J.S. \& Walstra, P. (1989). Physical 
changes in the fat globules in unhomogenized and homogenized milk. International Dairy Federation

Received 7 October 1996, revised and accepted 29 May 1997
Bulletin, no. 238. Pp. 13-16. Cited in Journal of Agricultural and Food Chemistry (1993), 41, 1407-1412. 